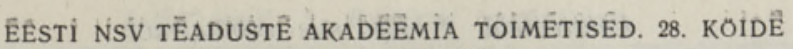
KEEMIA. 1979, NR. 2

ИЗВЕСТИЯ АКАДЕМИИ НАУК ЭСТОНСКОИ ССР, ТОМ 28

ХИМИЯ. 1979, № 2

В. СЛЕТ

удк 547.962

\title{
О РОЛИ БОКОВОЙ ЦЕПИ АМИНОКИСЛОТЫ ПРИ ОПРЕДЕЛЕНИИ КОНФОРМАЦИИ НЕКОТОРЫХ АМИНОКИСЛОТНЫХ ОСТАТКОВ В БЕЛКАХ
}

V. SLET. MONINGATE AMINOHAPPEJAAKIDE KORVALAHELA MOJUST PEAAHELA KONFORMAT. SIOONILE VALKUDES

V. SLET. THE INFLUENCE OF AMINO ACID SIDE CHAIN ON THE BACKBONE CONFORMATION OF SOME AMINO ACID RESIDUES IN PROTEINS

\section{Представлена О. Кирретом}

Ранее было показано $\left[{ }^{1,2}\right]$, что алкильные боковые радикалы R оказывают заметное влияние на стабильность развернутых структур (конформация $\mathrm{C}_{5}$ ) у сложных эфиров $\mathrm{N}$-ацетил- $\alpha$-аминокислот и это стерического характера вльияние реализуется двумя конкурирующими механизмами:

1. Рост объема * заместителя $\mathrm{R}$ обусловливает прогрессирующее отклонение углов $\varphi, \psi^{* *}$ в $\mathrm{C}_{5}$-конформации от $180^{\circ} \mathrm{C}$, что дестабилизирует эту структуру.

2. Рост объема заместителя $\mathrm{R}$ приводит к стабилизации конформации $\mathrm{C}_{5}$ ввиду эффекта Торпа-Ингольда (уменьшение валентного угла $\left.\mathrm{NC}^{\alpha} \mathrm{C}^{\prime}\right)$. В итоге стабильность конформации $\mathrm{C}_{5}$ определена условиями образования внутримолекулярной Н-связи $\mathrm{NH} \ldots 0$.<smiles>[R]OC(=O)C([R])NC(C)=O</smiles>

Конформация $\mathrm{C}_{5}$ у сложных эфиров $\mathrm{N}$-ацетил- $\alpha$-аминокислот (развернутая конформация стабилизирована внутримолекулярной Н-связью).

В белках встречаются развернутые конформации аминокислотных остатков в участках $\beta$-структуры, а также в клубкообразных участках. Факторы, стабилизирующие развернутые конформации аминокислотных остатков в белках и модельных пептидах, отличаются друг от друга. Но при неполярных боковых цепях $\mathrm{R}$ характер взаимодействия боковой и основной цепей дипептидной единицы<smiles>C1CC(C2CC2)C1</smiles>
аналогичных конформациях аминокислотного остатка быть в общих

\footnotetext{
* Имеется в виду увеличение и степень разветвленности радикала вблизи основной цепи.

** Обозначение атомов и углов в аминокислотных остатках дано согласно [3].
} 

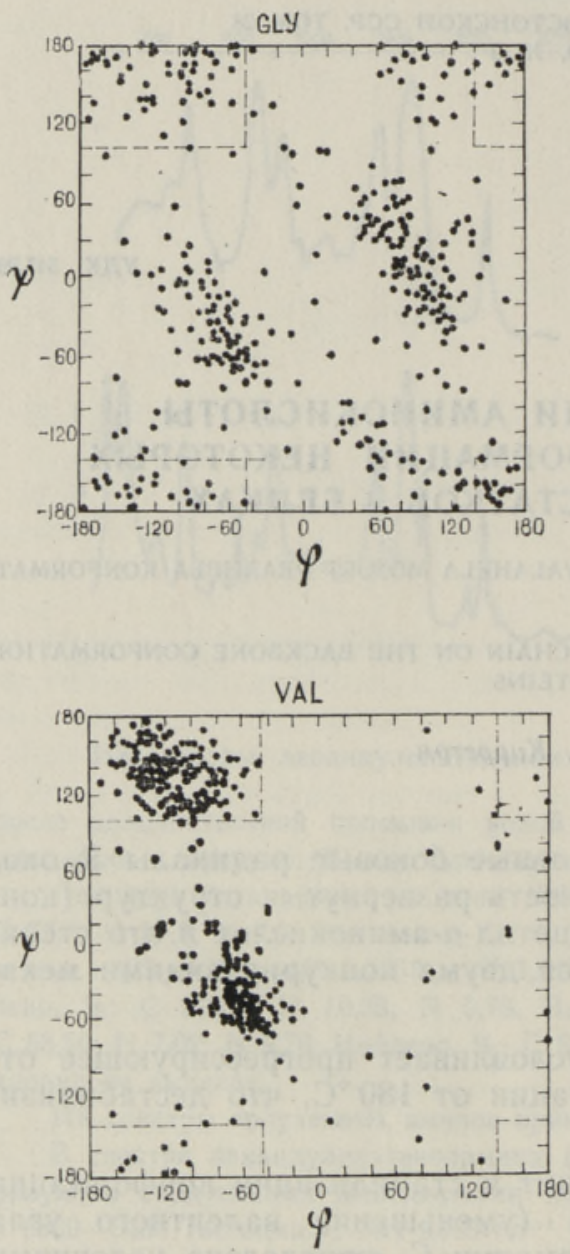

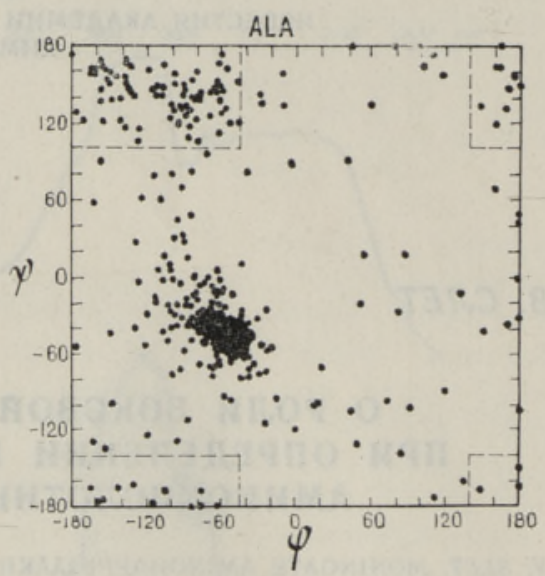

Распределение углов $\varphi$ и $\psi$ у аминокислотных остатков в 26 белках (согласно $\left.\left[{ }^{4}\right]\right): a-$ глицин, б - аланин, $в$ - валин. Область развернутых конформаций обозначена прерывистой линией.

чертах одинаков. Поэтому для выяснения роли-стерических взаимодействий боковой и основной цепей в пределах одной дипептидной единицы при определении конформации аминокислотных остатков в полипептидной цепи представляет интерес сравнение конформации аминокислотных остатков в модельных пептидах и белках.

Согласно [ $\left.{ }^{4}\right]$, в белках к развернутым структурам отнесены аминокислотные остатки с параметрами $-180^{\circ} \leqslant \varphi \leqslant-45^{\circ}$ и $100^{\circ} \leqslant \psi \leqslant$ $\leqslant 180^{\circ}$ или $-180^{\circ} \leqslant \psi \leqslant-140^{\circ} ;$ и $140^{\circ} \leqslant \varphi \leqslant 180^{\circ}$ и $100^{\circ} \leqslant \psi \leqslant 180^{\circ}$ или $-180^{\circ} \leqslant \psi \leqslant-140^{\circ}$.

На рисунке приведено статистическое распределение значений углов $\varphi$ и $\psi$ некоторых аминокислотных остатков в 26 белках (ссылки на оригинальные данные приведены в $\left.\left[{ }^{4}\right]\right)$. Сравнение $(a),(\sigma)$ и (в) (рисунок) показывает, что увеличение объема бокового радикала аминокислоты $\mathrm{R}$ приводит к уменьшению разброса значений углов $\varphi$ и $\psi$ в области развернутых конформаций и, аналогично модельным соединениям, к увеличению отклонения их среднего значения от $180^{\circ}$. Только среднее отклонение значений углов $\varphi, \psi$ от $180^{\circ}$ в белках несколько больше, чем в модельных пептидах. Рассмотрим это более подробно.

В отличие от приведенных модельных пептидов, где развернутые конформации аминокислотных остатков стабилизированы слабой внутримолекулярной Н-связью, в участках $\beta$-структуры белков основным фактором стабилизации развернутых структур аминокислотных остатков являются сильные межмолекулярные Н-связи. *** Для образования

*** Имеются в виду Н-связи между различными аминокислотными остатками. 
последних нет столь строгих конформационных ограничений, как в случае внутримолекулярных Н-связей. Действительно, например, в $\beta$-структурах развернутая конформация аминокислотного остатка может быть в заметной степени деформирована от плоской структуры без заметного ослабления межмолекулярных Н-связей ввиду соответствующего изменения углов $\varphi$ и $\psi$ (см. ниже формулу) у другого аминокислотного остатка или пространственного смещения последнего, в результате чего длины межмолекулярных Н-связей могут остаться неизменными. Поэтому компонент стерического взаимодействия боковой и основной цепей дипептидной единицы, направленный перпендикулярно плоскости двух соседних групп, не должен оказывать существенного влияния на энергетическое состояние $\beta$-структуры, и вполне естественно, что под влиянием этого компонента стерического взаимодействия происходит несколько бо́льшая деформация планарности развернутых конформаций аминокислотного остатка, чем в модельных пептидах.<smiles>[R]CN(C(C)=O)C(=O)C([R])NC([R])C([R])NC</smiles>

Участок $\beta$-структуры (антипараллельный складчатый слой).

Нелегко точно предсказать возможное влияние второго компонента стерического взаимодействия боковой и основной цепей дипептидной единицы, действующего в плоскости двух соседних пептидных групп и стабилизирующего в модельных пептидах конформацию $\mathrm{C}_{5}$ уменьшением валентного угла $\mathrm{NC}^{\alpha} \mathrm{C}^{\prime}$, на стабильность развернутых конформаций аминокислотных остатков в белках. Но в $\beta$-структурах этот, а также перпендикулярный компоненты стерического взаимодействия направлены таким образом, что ограничивают конформационную подвижность полярных группировок основной цепи и способствуют фиксированию их положения, увеличивая этим стабильность системы Н-связей (формула). Увеличению вероятности встречи развернутых структур аминокислотного остатка при росте объема боковой цепи способствует также энтропийный фактор. Исходя из этих соображений, естественно ожидать, что с ростом объема боковой цепи аминокислоты происходит некоторое увеличение стабильности развернутых конформаций аминокислотного остатка в белках.

В таблице приведены некоторые результаты статистического анализа рентгеноструктурных данных 26 (или 15) белков $\left[{ }^{4,5}\right]$ (аминокислотные остатки расположены в порядке ожидаемого увеличения стабильности развернутых конформаций). В кристаллах белков доля приведенных аминокислотных остатков в $\alpha$-спиральных участках изменяется случайным образом, в то время как суммарная доля амино- 
Содержание аминокислотных остатков в 26 (15)

белках в различных выделенных конформационных состояниях, \%

\begin{tabular}{|c|c|c|c|}
\hline $\begin{array}{l}\text { Амино- } \\
\text { кислоты }\end{array}$ & $\begin{array}{c}\text { Доля } \\
\text { развер- } \\
\text { нутых } \\
\text { конфор- } \\
\text { маций * }\end{array}$ & $\begin{array}{l}\text { Доля в } \\
\beta \text {-струк- } \\
\text { турах ** }\end{array}$ & $\begin{array}{c}\text { Доля } \\
\text { право- } \\
\text { вращаю- } \\
\text { щей } \\
\alpha \text {-спи- } \\
\text { рали * }\end{array}$ \\
\hline $\begin{array}{l}\text { Gly } \\
\text { Ala } \\
\text { Phe } \\
\text { Leu } \\
\text { Val } \\
\text { Ile }\end{array}$ & $\begin{array}{l}23,4 \\
25,6 \\
34,0 \\
35,9 \\
46,2 \\
44,0\end{array}$ & $\begin{array}{l}13,8 \\
16,7 \\
21,9 \\
20,9 \\
28,2 \\
27,4\end{array}$ & $\begin{array}{l}15,0 \\
43,0 \\
34,7 \\
38,4 \\
30,7 \\
32,9\end{array}$ \\
\hline $\begin{array}{l}\text { Iо данны } \\
\text { Іо данны }\end{array}$ & & & \\
\hline
\end{tabular}

кислотных остатков в развернутых конформациях и доля их в $\beta$-структурах в отдельности увеличиваются практически в порядке, предсказанном на основе результатов изучения модельных пептидов. Единственным отклонением от предсказанного является некоторое уменьшение доли развернутых структур при переходе $\mathrm{Val} \rightarrow \mathrm{Ile}$ вместо ожидаемого увеличения.

Следует отметить, что наряду с аминокислотными остатками с алкильной боковой цепью остатки Phe занимают в приведенном ряду именно то место, которое было предсказано на основе анализа модельных соединений, хотя механизм стабилизации развернутой структуры основной цепи аминокислоты с боковым радикалом $\mathrm{CH}_{2} \mathrm{C}_{6} \mathrm{H}_{5}$ имеет в модельных пептидах несколько иной характер, чем в случае алкильных боковых радикалов $\mathrm{R}\left[{ }^{1,2}\right]$. Такое совпадение указывает на роль энтропийного фактора.

Таким образом, из результатов анализа конформации аминокислотных остатков в 26 (или 15) белках следует, что встречаемость у развернутых конформаций приведенных аминокислотных остатков в белках и общая тенденция изменения углов $\varphi$ и $\psi$ при переходе от одного аминокислотного остатка к другому имеют определенную закономерность, а именно: при увеличении объема алкильной боковой цепи аминокислоты увеличиваются 1) вероятность встречи данного аминокислотного остатка в развернутых конформациях, в том числе и в $\beta$-структуре, и 2) деформация планарности основной цепи аминокислотного остатка в этой структуре.

Существование отмеченных закономерностей в белках и определенного параллелизма во влиянии боковой цепи аминокислоты на конформации ее основной цепи в модельных пептидах и белках указывает на то, что при образовании конформации белков, в данном случае $\beta$-структур и развернутых конформаций аминокислотных остатков в клубкообразных участках, наряду с другими факторами существенную роль могут сыграть и взаимодействия боковой и основной цепей дипептидной единицы. 


\section{ЛИТЕРАТ У РА}

1. Slet, V., Arro, I., L umiste, T. ${ }^{1} \mathrm{H}-\mathrm{NMR}$ and IR study of the conformations of $\mathrm{N}$-acetyl- $\alpha$-amino acid esters in solution. - In: Abstracts XXth Congress AMPERE. Tallinn, 1978, D 4416.

2. С лет В. А. Влияние боковой цепи аминокислоты на конформацию основной цепи у сложных эфиров $\mathrm{N}$-ацетил- $\alpha$-аминокислот (в печати).

3. IUPAC-IUB Commission on Biochemical Nomenclature. Abbreviations and symbols for the description of the conformation of polypeptide chains. - Biochem. J., 1971 , v. $121, \mathrm{~N} 4$, p. $577-585$.

4. T a naka, S., Scheraga, H. A. Statistical mechanical treatment of protein conformation. 5. A multistate model for specific sequence copolymers of amino acids. - Macromolecules, 1977, v. 10, N 1, p. 9-20.

5. Chou, P., F a sman, G. D. Conformational parameters for amino acids in helical, $\beta$-sheet, and random coil regions calculated from proteins. - Biochemistry, 1974 , v. 13 , N 2, p. $211-222$

Институт термофизики и электрофизики Академии наук Эстонской ССР

Поступила в редакцию $10 / 11979$

EESTI NSV TEADUSTE AKADEEMIA TOIMETISED. 28. KOIDE KEEMIA. 1979, NR. 2

ИЗВЕСТИЯ АКАДЕМИИ НАУК ЭСТОНСКОИ ССР. ТОМ 28 Химия. 1979, № 2

удк $547.686: 542.943 .5: 541.141 .8$

Helvi UIBOPUU, Lia PAALME, J. PAHAPILL, M. GUBERGRITS, Odette PERIN-ROUSSEL, Martine CROISY-DELCEY, P. JACQUIGNON

\section{FLUORANTEENI BENSO- JA NAFTODERIVAATIDE INITSIEERITUD OKSÜDEERIMISEST}

ХеАьвИ УПБОПУУ, ЛИа ПААЛЬМЕ, Ю. ПАХАПИЛЛЬ, М. ГУБЕРГРИЦ, ОдетТ ПЕРЭН-РУССЕЛЬ, Мартин КРУАЗИ-ДЕЛЬСЕИ, П. ЖАКИНЬОН. ОБ ИНИЦИИРОВАННОМ ОКИСЛЕНИИ БЕНЗО- И НАФТОПРОИЗВОДНЫХ ФЛУОРАНТЕНА

Helvi UIBOPUU, Lia PAALME, J. PAHAPILL, M. GUBERGRITS, Odette PERIN-ROUSSEL, Martine CROISY-DELCEY, P. JACQUIGNON. ABOUT THE INITIATED OXIDATION OF BENZOAND NAPHTHOFLUORANTHENES

Varem on uuritud mõningate polütsükliliste areenide lagundamist ultraviolett- ja $\gamma$-kiirguse toimel ja proovitud saadud formaalkineetika andmeid vastavusse viia mõnede kvantkeemia näitajatega $\left[{ }^{1-4}\right]$. Fluoranteenid on valitud uuringute objektiks põhjusel, et paljud neist on kantserogeensed (näit. dibenso (a,e)fluoranteen) ja esinevad kütuste töötlemisproduktides. Seega oleks nende lagundamise võimaluste ja seaduspärasuste uurimine otsene jätk varasematele töödele kantserogeensete ühendite valdkonnas.

Enamik uuritud fluoranteene (ühendid II-VII; vt. tab.) on sünteesitud Prantsusmaa Teaduslike Uurimistööde Rahvusliku Keskuse Loodus- 